\title{
Ontogenetic habitat shifts affect performance of artificial shelters for Caribbean spiny lobsters
}

\author{
Enrique Lozano-Álvarez ${ }^{1, *}$, César Meiners ${ }^{1,2}$, Patricia Briones-Fourzán ${ }^{1}$ \\ ${ }^{1}$ Instituto de Ciencias del Mar y Limnología, Unidad Académica Puerto Morelos, Universidad Nacional Autónoma de Mexico, \\ PO Box 1152, Cancún, Quintana Roo 77500, Mexico \\ ${ }^{2}$ Present address: Unidad de Investigación de Ecología de Pesquerías, Universidad Veracruzana, Av. Hidalgo 617, \\ Col. Río Jamapa, Boca del Río, Veracruz 94290, Mexico
}

\begin{abstract}
Early benthic juveniles (EBJ) of Caribbean spiny lobster Panulirus argus dwell solitarily in vegetated habitats but eventually shift to dwelling gregariously in crevice shelters ('crevices'). This habitat shift may depend on the interplay between the refuge value of the local vegetation (which increases with complexity) and that of available crevices (which increases with the potential they offer for gregariousness). We examined how these factors influenced density enhancement of lobsters with large artificial shelters ('casitas', $1.1 \mathrm{~m}^{2}$ in refuge area) in a coastal reef lagoon. We deployed 10 casitas at each of five 1 ha sites, 3 located in the mid-lagoon zone (ML) and 2 in the back-reef lagoon zone (BRL). These zones differed in vegetation complexity and abundance of algal-dwelling EBJ (greater in the ML), and abundance of crevices (greater in the BRL). Over 4 yr (22 surveys), abundance of large juveniles (>20 mm carapace length, CL) was initially higher in casitas in the BRL but tended to converge over time between lagoon zones, whereas EBJ ( $\leq 20 \mathrm{~mm} \mathrm{CL}$ ) were consistently more abundant in casitas in the BRL. Even when controlling for a potentially stronger conspecific chemical attraction exerted by greater aggregations of large juveniles in BRL casitas, significantly more EBJ shifted to casitas in the BRL than in the ML. Thus, lobster density enhancement with casitas was more immediate in the BRL, where the local vegetation ceased to protect lobsters sooner, but increased over time in the more lushly vegetated ML as gradually more lobsters shifted to, and persisted in, casitas.
\end{abstract}

KEY WORDS: Density enhancement · Gregariousness · Ontogenetic habitat shifts · Panulirus argus · Reef lagoon Resale or republication not permitted without written consent of the publisher

\section{INTRODUCTION}

Seagrass-macroalgal meadows constitute nursery habitats for many species of marine animals that shift to other habitats as they grow (Hemminga \& Duarte 2000, Heck et al. 2003). For these species, habitat shifts may depend on the landscape context (the spatial patterning of habitats) and the relative levels of predation risk, availability of food and shelter, and competitive interactions in different habitats, which may affect conspecifics of different sizes in different ways (Werner \& Gilliam 1984, Eggleston et al. 1998, Hovel \& Lipcius 2001, Stoner 2003). Understanding the relative importance of factors modulating habitat shifts can provide valuable insights into the effects of habitat fragmentation on local populations (Eggleston et al. 1998, Acosta 1999, Hovel \& Lipcius 2001, Tanner 2006) and into the mechanisms underlying the ecological performance of artificial structures to enhance target species (e.g. Powers et al. 2003).

The Caribbean spiny lobster Panulirus argus (Latreille, 1804), which sustains important fisheries across the Greater Caribbean region, undergoes several ontogenetic habitat shifts (see Childress \& Herrnkind 1994, Butler \& Herrnkind 1997). Following a lengthy pelagic larval phase, the postlarvae (5 to $6 \mathrm{~mm}$ cara- 
pace length, CL) settle in shallow vegetated habitats, where the early benthic juveniles (EBJ, 6 to $20 \mathrm{~mm} \mathrm{CL}$ ) remain widely dispersed. After a few months, EBJ emerge from the vegetation to seek daytime refuge in crevice-type shelters within or adjacent to the vegetated habitats (e.g. solution holes and crevices, coral heads, the bases of large sponges and soft corals) and become socially gregarious. Subsequent habitat shifts include a subadult (35-45 to $75-80 \mathrm{~mm} \mathrm{CL}$ ) shift to patch reefs and shallow coral reef habitats, followed by an eventual shift to deeper reefs by the adults (75-80 to $>200 \mathrm{~mm} \mathrm{CL)}$. Lobsters of all sizes have a broad diet spectrum (Cox et al. 1997, Briones-Fourzán et al. 2003), but foraging ranges increase from a few meters for EBJ to hundreds of meters for subadults and adults (Herrnkind \& Butler 1986, Butler \& Herrnkind 1997, Cox et al. 1997), resulting in considerable habitat overlap between benthic phases (Lozano-Álvarez et al. 1991, 2007).

Habitat shifts involve trade-offs between foraging benefits and predation risk (Werner \& Gilliam 1984, Childress \& Herrnkind 1994, Dahlgren \& Eggleston 2000). Panulirus argus lobsters, which are omnivorous, are usually not food-limited (Briones-Fourzán et al. 2003, Nizinski 2007) but are prey to numerous predators, particularly diurnal fishes (Smith \& Herrnkind 1992). However, their risk of predation tends to be inversely related to their body size and to the refuge value of available shelter (Eggleston \& Lipcius 1992, Smith \& Herrnkind 1992, Butler et al. 1997). For algaldwelling EBJ, survival largely depends on the complexity of the local vegetation (Marx \& Herrnkind 1985, Herrnkind \& Butler 1986, Briones-Fourzán \& Lozano-Álvarez 2001a, Cruz et al. 2007), which tends to increase with plant density (Orth et al. 1984, Eggleston et al. 1998, Hemminga \& Duarte 2000). For crevice-dwelling lobsters, survival depends on complex interactions between crevice size, lobster size, conspecific density and predation risk, but tends to increase where available crevices offer the potential for gregariousness (Eggleston et al. 1990, Mintz et al. 1994). Gregariousness is mediated by chemical scents released by sheltered lobsters that attract other lobsters seeking shelter (the 'guide effect benefit', Childress \& Herrnkind 2001a,b). As the scent production is mass-dependent, crevices harboring more lobsters potentially exert a stronger guide effect (Ratchford \& Eggleston 1998). Spiny lobsters use their long, spiny antennae to fend off predators, but this defense mechanism is less effective for smaller than for larger lobsters because antennal strength increases with body size (Briones-Fourzán et al. 2006), and for solitary than for aggregated lobsters because the latter jointly use their antennae as defensive weapons (the 'group defense benefit'). However, in crevices that harbor a broad size spectrum of lobsters, the smaller lobsters benefit from the greater individual and collective defensive abilities of the larger lobsters (Eggleston \& Lipcius 1992, Mintz et al. 1994, Briones-Fourzán \& Lozano-Álvarez 2008).

Therefore, the shift of Panulirus argus EBJ from algal- to crevice-dwelling likely occurs sooner where the refuge value of available crevices is higher than that of the local vegetation, and later where vegetation offers a more meaningful refuge than available crevices (Childress \& Herrnkind 1994, 2001a, Lipcius et al. 1998). Regardless, juvenile lobsters will eventually outgrow the protection afforded by vegetation, and if crevices are unavailable or unsuitable, a local demographic bottleneck may ensue (Eggleston et al. 1990, Briones-Fourzán et al. 2007). Several studies, however, have shown that deployment of artificial shelters can mitigate paucity of natural crevice shelter for juvenile $P$. argus (e.g. Mintz et al. 1994, Butler \& Herrnkind 1997, Sosa-Cordero et al. 1998, BrionesFourzán \& Lozano-Álvarez 2001b).

In particular, a 5 yr-long field experiment conducted in a reef lagoon poor in crevice shelter (Puerto Morelos, Mexico) showed that deployment of large artificial shelters ('casitas') at 5 sites ('casita sites') enhanced density, survival and persistence of juvenile Panulirus argus relative to 4 control sites and to pre-deployment values (Briones-Fourzán et al. 2007). However, Briones-Fourzán \& Lozano-Álvarez (2001b) reported that, during the first year post-deployment alone, lobster abundance was much higher at casita sites located in the back-reef lagoon zone (BRL), where natural crevices abounded, than at casita sites located in the mid-lagoon zone (ML), where natural crevices were much scarcer. Given the small size of lobsters residing in casitas at that time $(28.4 \pm 9.8 \mathrm{~mm} \mathrm{CL}$, mean $\pm \mathrm{SD})$, these authors postulated that perhaps, over a longer timeframe, the difference in lobster abundance between BRL and ML casita sites would become less marked (i.e. would tend to converge over time) as gradually more lobsters survived to a size at which their movement range was increased (i.e. lobsters would tend to move indistinctly between BRL and ML casita sites as their size increased).

Using data from 4 yr post-deployment, we found that the abundance of lobsters did tend to converge over time between casita sites in the BRL and the ML in this study. However, a capture-recapture experiment revealed that lobsters of 20 to $80 \mathrm{~mm}$ CL did not tend to move between sites but rather persisted for months in their original site until presumably shifting to the nearby reef habitat (Briones-Fourzán et al. 2007). Therefore, other factors may have contributed to the convergent pattern. For example, differences in habitat complexity - including vegetation and availability 
of crevices - may have resulted in a differential effect of casitas on the larger, fully crevice-dwelling lobsters ('large juveniles', >20 mm CL), and the smaller, habitat-transitional EBJ ( $\leq 20 \mathrm{~mm} \mathrm{CL}$ ). Therefore, we separately tested for a convergence over time in the abundances of large juveniles and EBJ residing in casitas, and compared habitat complexity, abundance of algaldwelling EBJ, and microhabitat value of natural crevices and casitas between ML and BRL sites. We predicted that if casitas offered better refuge for large juveniles than available crevices, then large juveniles would tend to use casitas rather than crevices regardless of lagoon zone. The more large juveniles aggregated in casitas, the greater the potential guide effect leading nearby EBJ to shift to casitas, given that small lobsters prefer to reside gregariously in large crevices with larger conspecifics than remain solitary in small shelters (Eggleston \& Lipcius 1992). However, because the shift of EBJ to casitas would also depend on the local risk of predation (Eggleston \& Lipcius 1992), we predicted that this shift would be modulated by the complexity (i.e. refuge value) of the local vegetation.

\section{MATERIALS AND METHODS}

Study area. The Puerto Morelos reef lagoon is located on the northeastern coast of the Yucatan Peninsula, Mexico $\left(20^{\circ} 40^{\prime}\right.$ to $21^{\circ} 12^{\prime} \mathrm{N}$ and $86^{\circ} 47^{\prime}$ to $86^{\circ} 58^{\prime} \mathrm{W}$ ) and is delimited on the seaward side by an extended fringing coral reef situated 500 to $2000 \mathrm{~m}$ from the shore. The shallow reef lagoon $(\leq 5 \mathrm{~m}$ in water depth) sustains a macrophyte community dominated by the seagrasses Thalassia testudinum and Syringodium filiforme, with an algal understory composed of numerous species of macroalgae. Calcareous algae (Halimeda spp.) are the dominant macroalgae, but drift algae (almost exclusively Lobophora variegata) can be locally highly abundant (Reyes-Zavala 1998, Briones-Fourzán \& Lozano-Álvarez 2001a, van Tussenbroek \& van Dijk 2007). Based on general characteristics of the vegetation, depth, and wave exposure, Ruiz-Rentería et al. (1998) divided the reef lagoon into 3 zones following a gradient from coast to reef: a narrow coastal zone, a broader mid-lagoon zone, and a back-reef lagoon zone (Fig. 1).

Experimental setup. The present study stemmed from the field experiment reported by Briones-Fourzán et al. (2007), which was originally designed to compare response variables of lobsters between a group of 4 control sites (without casitas) and a group of 5 casita sites (with casitas) demarcated across the reef lagoon. Each site measured $100 \times 100 \mathrm{~m}$ (= $1 \mathrm{ha}$ ) and was separated from adjacent sites and from the coral reef tract by distances of 200 to $600 \mathrm{~m}$ to ensure statistical independence. Given

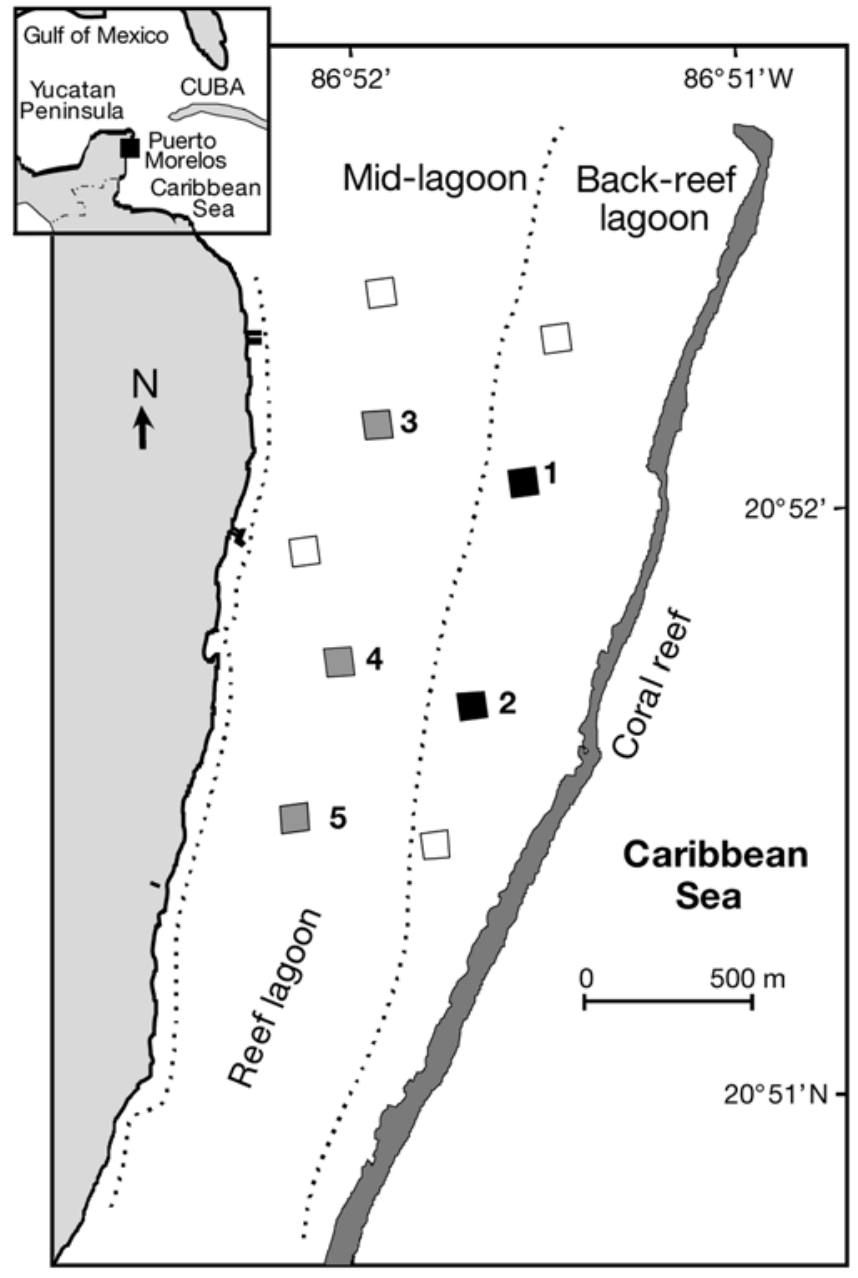

Fig. 1. The Puerto Morelos reef lagoon (Mexico) showing the location of the original casita sites (filled squares) and control sites $(\square)$ of Briones-Fourzán et al. (2007). Each site measured $100 \times 100 \mathrm{~m}$ and casita sites contained 10 casitas each. Dotted lines denote approximate limits of the mid-(ML) and backreef lagoon (BRL) zones. Casitas sites 1 and 2 ( $\square$ ) were located in the BRL and casita sites 3 to $5(\square)$ were located in the ML

the narrowness of the reef lagoon, this resulted in the location of 2 casita sites and 2 control sites in the BRL, and 3 casita sites and 2 control sites in the ML (Fig. 1). In July 1998, 10 casitas were randomly deployed at each casita site (50 casitas in total) but leaving a distance of $\sim 20 \mathrm{~m}$ between adjacent casitas. Casitas consisted of a flat ferro-cement slab, $1.1 \mathrm{~m}^{2}$ in surface area, bolted to a double-stack frame built with $3.8 \mathrm{~cm}$ diameter PVC pipes (Fig. 2). On 22 occasions from September 1998 to November 2002, we counted and measured (CL, mm), while on SCUBA, all lobsters occupying casitas and natural crevices within each site. Only data from casita sites were relevant to the present study, given its aim to compare habitat structure and lobster variables exclusively between BRL and ML casita sites, but the locations of the control sites used by Briones-Fourzán et al. (2007) 


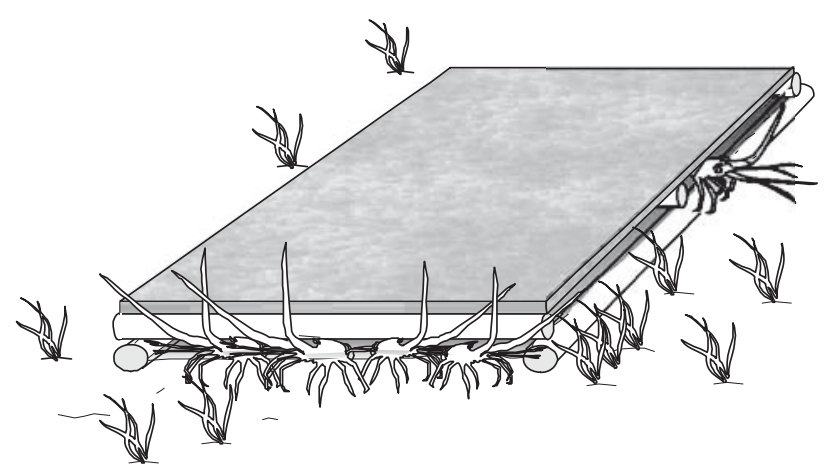

Fig. 2. Schematic representation of a casita (not to scale)

are also shown in Fig. 1 because it was often necessary to refer to those sites.

Statistical analyses. As lobster variables were measured at the same sites over successive surveys, some comparisons involved the use of repeated-measures analysis of variance (RM-ANOVA) to test the effects of Lagoon Zone $(L Z$, with 2 levels, BRL and $M L$, and 2 replicate sites for BRL and 3 for $\mathrm{ML}$ ), Time ( $T$, with 22 levels corresponding to 22 surveys), and the $L Z \times T$ interaction. In all cases, the data were appropriately transformed to comply with ANOVA assumptions as tested with Levene's test. In cases where data showed serial correlation, which violates the assumption of sphericity, the resulting Huynh-Feldt estimator was used to adjust the degrees of freedom of $T$ and its residuals in order to homogenize the variance-covariance matrix (Howell 2002).

Convergence over time between lagoon zones in the abundance of lobsters using casitas. We first tested for a convergence over time between lagoon zones in the abundance of all lobsters observed exclusively in casitas, and then separately tested for a convergence in the abundance of large juveniles and EBJ. In all 3 cases, the data, previously transformed to $\log$ (number +1 ), were subjected to a RM-ANOVA to test the effects of $L Z, T$, and $L Z \times T$. We expected a significant effect of $T$ in all cases (Briones-Fourzán et al. 2007), but a significant effect of $L Z \times T$ would indicate differential changes over time within lagoon zones. To test whether these changes resulted in convergence over time in lobster abundance between lagoon zones, we subtracted the mean values of ML sites from the mean values of BRL sites for each survey and subjected the difference in means to a linear correlation analysis. A negative, significant trend would indicate convergence (Briones-Fourzán et al. 2007 and references therein).

Habitat characteristics of individual casita sites. Previous studies (e.g. van Tussenbroek 1995, 1998, Reyes-Zavala 1998, Ruiz-Rentería et al. 1998, Enríquez et al. 2001) have established that vegetation in the Puerto Morelos reef lagoon is typically more complex in the ML than in the BRL, but to test our predictions it was necessary to characterize the vegetated habitat within our casita sites. To facilitate this characterization, each site was divided into 50 subareas, $200 \mathrm{~m}^{2}$ each. At all intersection points between subareas $(\mathrm{n}=$ 66), we measured sediment depth, an important predictor variable for seagrass abundance (Fourqurean et al. 2003), by probing with a steel rod to the bedrock, and from extensive visual surveys we established the presence of 4 'vegetation types' (VT1 to VT4) of apparent decreasing complexity (see below). In March to May 2001, we used a rapid assessment technique to estimate the density (\% cover) of every VT on each subarea within each site using a set of modified Braun-Blanquet scores (e.g. Fourqurean et al. 2001). These scores, and their respective \% cover were $0(0 \%), 0.5(<1 \%), 1 \quad(1-10 \%), 2 \quad(10-25 \%)$, $3(25-50 \%), 4(50-75 \%)$, and $5(75-100 \%)$. For each site and VT, the scores were averaged across all subareas to yield a Braun-Blanquet density estimate (Fourqurean et al. 2001, 2003).

To provide quantitative estimates for the VTs, we randomly tossed a $0.01 \mathrm{~m}^{2}$ quadrat at least 19 times onto large patches representative of each VT. In each quadrat, we counted the shoots or thalli of 3 plant components, Thalassia testudinum, Syringodium filiforme, and all types of macroalgae (with the exception of drift algae, see below), and measured the longest leaf per shoot in 25 shoots of each seagrass species (van Tussenbroek 1998). All variables, previously transformed to square root (count +0.5$)$ and $\log ($ length +1$)$, differed significantly among VTs (separate 1-way ANOVAs, all $\mathrm{p}$ values $\leq 0.001$ ). The length of both seagrasses tended to decrease from VT1 to VT4, but $T$. testudinum was longer than $S$. filiforme in all VTs (Table 1). Densities of individual plant components varied widely among VTs (Table 1). Density of macroalgae was higher in VT4 but did not differ significantly among VT1 to VT3. Density of S. filiforme was higher in VT2 and lower in VT4, with intermediate values in VT1 and VT3, whereas density of $T$. testudinum was higher in VT1 and VT3 than in VT2 and VT4. Despite the lower densities of $T$. testudinum relative to $S$. filiforme in some VTs, T. testudinum is the dominant seagrass in terms of biomass (Enríquez et al. 2001) because its flat leaves are much wider (8 to $12 \mathrm{~mm}$, van Tussenbroek 1998) than the thin cylindrical leaves of $S$. filiforme (1.2 to $1.7 \mathrm{~mm}$ in diameter, van Tussenbroek 1994). The combined density of the 3 plant components was higher in VT1 and VT2, intermediate in VT3, and lower in VT4 (Table 1). Based on these attributes, we considered that VT1 to VT4 represented a decreasing gradient in vegetation complexity. 
Table 1. Characterization of 4 vegetation types (VT1 to VT4) used to assess vegetation complexity at casita sites in the Puerto Morelos reef lagoon, based on the mean length $( \pm \mathrm{SE})$ of the longest leaf per shoot $(\mathrm{n}=25$ shoots per quadrat) of 2 seagrass species (Thalassia testudinum and Syringodium filiforme) and mean density ( \pm SE) of plants categorized into 3 plant components: the 2 seagrass species and macroalgae (excluding drift algae). For each column, matching superscript letters denote statistically similar groups

\begin{tabular}{|c|c|c|c|c|c|c|c|}
\hline \multirow{2}{*}{$\begin{array}{l}\text { Vegetation } \\
\text { type }\end{array}$} & \multirow{2}{*}{$\begin{array}{c}\mathrm{N} \\
\text { quadrats }\end{array}$} & \multicolumn{2}{|c|}{ Foliar length $(\mathrm{cm})-$} & \multicolumn{4}{|c|}{ Density (number of shoots or thalli $\mathrm{m}^{-2}$ ) } \\
\hline & & T. testudinum & S. filiforme & T. testudinum & S. filiforme & Macroalgae & Total plants \\
\hline VT1 & 20 & $24.4 \pm 2.0^{\mathrm{a}}$ & $18.7 \pm 2.0^{\mathrm{a}}$ & $561 \pm 70^{\mathrm{a}}$ & $1022 \pm 297^{\mathrm{ab}}$ & $183 \pm 53^{\mathrm{b}}$ & $1767 \pm 278^{\mathrm{a}}$ \\
\hline VT2 & 19 & $23.5 \pm 1.3^{\mathrm{a}}$ & $18.9 \pm 1.0^{\mathrm{a}}$ & $253 \pm 49^{\mathrm{b}}$ & $1284 \pm 107^{\mathrm{a}}$ & $284 \pm 53^{\mathrm{ab}}$ & $1821 \pm 158^{a}$ \\
\hline VT3 & 20 & $16.8 \pm 1.7^{\mathrm{b}}$ & $11.5 \pm 1.1^{\mathrm{b}}$ & $428 \pm 52^{\mathrm{a}}$ & $567 \pm 148^{\mathrm{bc}}$ & $189 \pm 35^{\mathrm{b}}$ & $1183 \pm 97^{\mathrm{b}}$ \\
\hline VT4 & 50 & $10.8 \pm 0.6^{\mathrm{c}}$ & $9.5 \pm 0.5^{\mathrm{b}}$ & $257 \pm 23^{b}$ & $266 \pm 40^{\mathrm{c}}$ & $326 \pm 24^{\mathrm{a}}$ & $848 \pm 48^{\mathrm{c}}$ \\
\hline
\end{tabular}

Drift algae were not included in our VTs because they typically form extensive carpets that make it difficult to estimate their density. However, because drift algae are particularly important as a microhabitat for algal-dwelling EBJ of Panulirus argus (Marx \& Herrnkind 1985, Herrnkind \& Butler 1986, Briones-Fourzán \& Lozano-Álvarez 2001a, Cruz et al. 2007), we quantified the biomass of drift algae at our sites. All fronds of Lobophora variegata (the only drift alga present at our sites) within a $0.04 \mathrm{~m}^{2}$ quadrat randomly tossed at least 10 times onto each site (B. I. van Tussenbroek unpubl. data) were cut at bottom level, dried at $100^{\circ} \mathrm{C}$ for $24 \mathrm{~h}$, and weighed to the nearest $0.1 \mathrm{~g}$. The biomass data (g dry wt $\mathrm{m}^{-2}$ ) were compared among sites with a Kruskal-Wallis test followed by a test on medians (Zar 1999).

Abundance and mean size of algal-dwelling EBJ. Throughout the year, Panulirus argus postlarvae arrive into, and settle across, the Puerto Morelos reef lagoon (Briones-Fourzán \& Lozano-Álvarez 2001a, BrionesFourzán et al. 2008). To compare the abundance of algal-dwelling EBJ between lagoon zones, we reanalyzed data obtained by Briones-Fourzán \& LozanoÁlvarez (2001a) in 2 different years prior to casita deployment (June 1995 and March 1998). Samples were taken at night (20:00 to 21:00 h) at 2 sites located in the BRL and 3 sites located in the ML. At each site, the sampling unit had a bottom area of $342 \mathrm{~m}^{2}$. This was the average area sampled by an epibenthic net (mouth dimensions: $0.57 \mathrm{~m}$ in width and $0.25 \mathrm{~m}$ in height; mesh size: $1 \mathrm{~mm}$ ) trawled 10 times for $1 \mathrm{~min}$ each at a speed of $1 \mathrm{~m} \mathrm{~s}^{-1}$. The trawling operations were monitored by a diver to ensure that the net performed properly and that successive trawls did not overlap. The numbers and sizes of EBJ from each sampling unit - transformed to $\log (\mathrm{count}+1)$ and $\log (\mathrm{CL}+$ 1), respectively - were subjected to separate factorial ANOVAs to test for effects of $L Z$ (with 2 levels, ML and BRL), Year (with 2 levels, 1995 and 1998), and the $L Z \times$ Year interaction.

Availability and microhabitat value of natural crevices. To assess the potential for gregariousness offered by natural crevices (further referred to as 'crevices'), we compared the distribution of lobsters residing in crevices among occupied crevices to a random (zero-truncated Poisson) distribution (Cohen 1960), and used a 1-way ANOVA to compare their mean size between BRL and ML sites. During 2000, we counted all crevices available at each site, but their actual refuge area was difficult to measure due to their irregular shapes. Therefore, we used their largest external diameter as a proxy (Briones-Fourzán \& Lozano-Álvarez 2001b) and compared the proportions of small $(<25 \mathrm{~cm}$ across largest diameter $)$, medium $(25$ to $50 \mathrm{~cm})$, and large crevices $(>50 \mathrm{~cm})$ among sites with a $\chi^{2}$ contingency table (Zar 1999).

Microhabitat value of casitas. To assess the potential for gregariousness offered by casitas, we compared the distribution of lobsters among casitas to a random (Poisson) distribution for each lagoon zone and used a RM-ANOVA to test for effects of $L Z, T$, and $L Z \times T$ on their mean size. In particular, we were interested in assessing whether casitas at BRL sites (which were closer to the reef tract, i.e. the adult habitat) harbored larger lobsters, which could indicate a gradual transition of lobsters from the primary settlement habitat to the adult habitat and/or a potential attraction of larger lobsters from the reef habitat to BRL casitas. We then used a 1-way ANOVA to compare the mean size of lobsters using casitas versus lobsters using crevices.

In November 2000, an experiment was conducted to evaluate the short-term site fidelity (propensity to remain within a site), casita fidelity (propensity to use the same casita), and range of shelter use of large juveniles using casitas in each lagoon zone. We marked in situ 56 large juvenile lobsters (22.0 to $58.6 \mathrm{~mm}$ CL) occupying casitas (28 at BRL sites and 28 at ML sites) with an individually color-coded wire twisted around the base of one antenna and immediately returned each individual to its original casita. The mean size of these lobsters (39.6 $\pm 2.7 \mathrm{~mm} \mathrm{CL})$ did not differ significantly with $L Z$ (Student's $t$-test on log-transformed data, $t_{54}=1.338, \mathrm{p}=0.093$ ). We then surveyed the sites for 6 consecutive days to record the daily location and the distance between casitas successively used by each individual (Lozano-Álvarez et al. 2003). Across 
a All lobsters

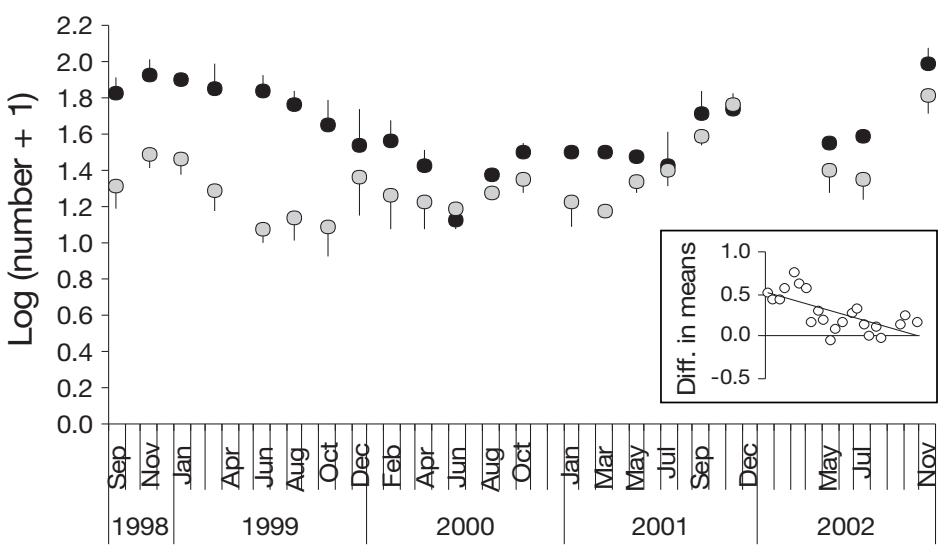

b Large juveniles

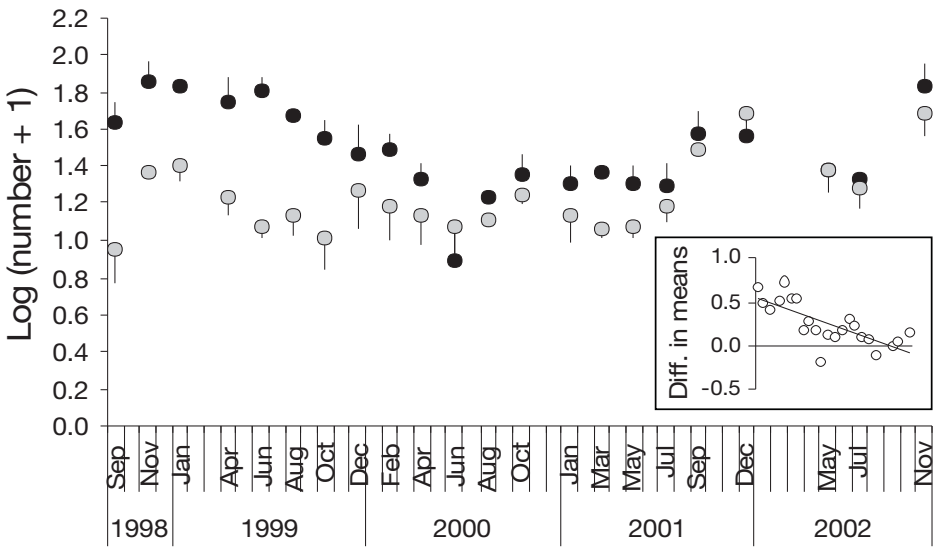

c Early benthic juveniles

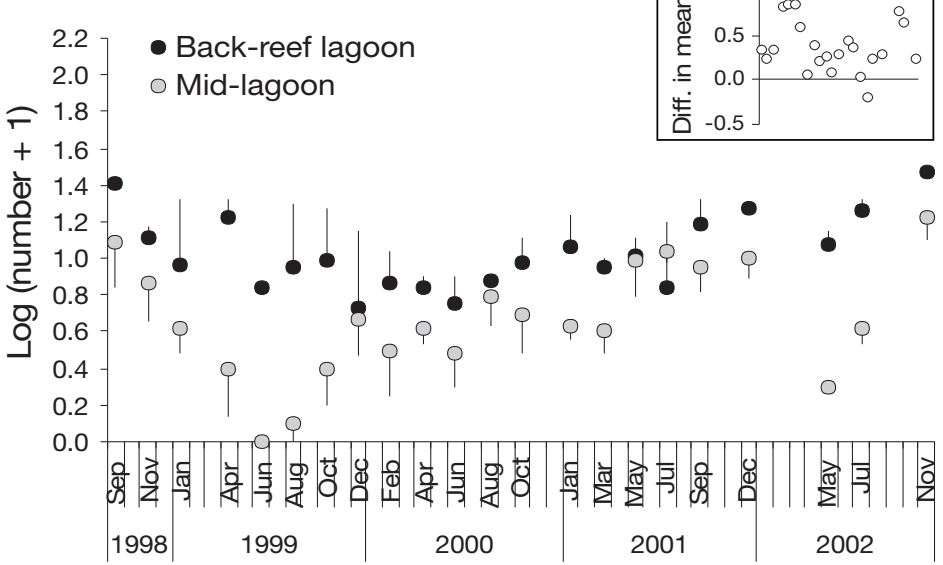

Fig. 3. Panulirus argus. Mean ( $\pm \mathrm{SE}$ ) abundance (log[number +1$]$ ) of (a) all lobsters (6.2 to $87.2 \mathrm{~mm}$ carapace length, CL), (b) large juveniles (>20 mm CL), (c) early benthic juveniles ( $\leq 20 \mathrm{~mm}$ CL) residing in casitas at sites in the back-reef (BRL, $\mathrm{n}=2$ sites) and the mid-lagoon ( $M L, n=3$ sites) during 22 surveys (September 1998 to November 2002). The inset in each panel shows the trend over time for the differences in means (BRL minus ML) the $6 \mathrm{~d}$ period, we tested the effect of $L Z$ on site fidelity (percent lobsters resighted at least once within the site) with a Fisher exact test, on casita fidelity (percent lobsters resighted in their original casitas) with a contingency table with $\chi^{2}$, and on range of shelter use (total distance moved between successive casitas over number of days) with a Student's $t$-test.

Effect of habitat complexity on the shift of EBJ to casitas. We expected the number of EBJ shifting to casitas to increase as more large juveniles aggregated in casitas, but given the lower complexity of the vegetated habitat at BRL sites (see 'Results: Habitat characteristics of individual casita sites'), we also expected that proportionally more EBJ would shift to casitas, and would tend to do so at a smaller size, in the BRL than in the ML. Therefore, we performed an analysis of covariance (ANCOVA) with the number of EBJs residing in casitas (averaged by survey) as the dependent variable, the corresponding number of large juveniles residing in casitas as the covariate, and $L Z$ as the categorical factor. The data, previously transformed to $\log ($ number +1$)$, were first subjected to a test of homogeneity of slopes (Howell 2002). This test showed that the covariate was linearly related to the dependent variable $\left(F_{1,40}=9.499, \mathrm{p}=0.004\right)$ and did not significantly interact with the categorical predictor $\left(F_{1,40}=0.639, \mathrm{p}=0.429\right)$; therefore, we proceeded with the ANCOVA. Then, the size data of EBJ residing in casitas (transformed to $\log (\mathrm{CL}+1)$ and averaged for site and survey) were subjected to a RM-ANOVA to test for effects of $L Z, T$, and $L Z \times T$.

Throughout the remaining text, results are expressed as mean \pm SE unless otherwise indicated. Statistical results were considered as significant if $\mathrm{p}<0.05$.

\section{RESULTS}

\section{Convergence over time between lagoon zones in abundance of casita-dwelling lobsters}

The 3 panels in Fig. 3 show the mean abundances per survey (derived from logtransformed data) of all lobsters, large juveniles, and EBJ residing in casitas at sites in each lagoon zone, and the inset in each panel shows the respective trend for the differences in means (BRL sites minus ML sites). The effect of $T$ was significant in all cases and the effect of $L Z \times T$ was significant for all lobsters and for large 
Table 2. Panulirus argus. RM-ANOVA for mean numbers of lobsters dwelling in casitas at sites in the back-reef lagoon $(\mathrm{BRL}, \mathrm{n}=$ 2 sites) and the mid-lagoon ( $M L, n=3$ sites) zones across 22 surveys (September 1998 to November 2002), and trends over time for the difference in mean numbers between lagoon zones (BRL minus ML). All lobsters: 6.2 to 87.2 mm carapace length (CL), large juveniles: $>20 \mathrm{~mm} \mathrm{CL}$, early benthic juveniles (EBJ): $\leq 20 \mathrm{~mm} \mathrm{CL}$. Each site measured 1 ha and contained 10 casitas. Data were transformed to $\log ($ number +1$)$ prior to analyses. Degrees of freedom were the same in all cases

\begin{tabular}{|c|c|c|c|c|c|c|c|c|c|c|}
\hline \multirow{2}{*}{ Effect } & \multirow[t]{2}{*}{$\mathrm{df}$} & \multicolumn{3}{|c|}{-All lobsters - } & \multicolumn{3}{|c|}{ - Large juveniles } & \multicolumn{3}{|c|}{$-\mathrm{EBJ}-$} \\
\hline & & MS & $F$ & $\mathrm{p}$ & MS & $F$ & $\mathrm{p}$ & MS & $F$ & $\mathrm{p}$ \\
\hline Lagoon Zone (LZ) & 1 & 2.108 & 11.567 & 0.042 & 1.715 & 6.843 & 0.079 & 3.585 & 41.329 & 0.008 \\
\hline Error & 3 & 0.182 & & & 0.251 & & & 0.087 & & \\
\hline Time $(T)$ & 21 & 0.139 & 5.947 & $<0.001$ & 0.161 & 6.990 & $<0.001$ & 0.242 & 3.345 & $<0.001$ \\
\hline$L Z \times T$ & 21 & 0.060 & 2.561 & 0.002 & 0.071 & 3.092 & $<0.001$ & 0.096 & 1.325 & 0.194 \\
\hline Error & 63 & 0.023 & & & 0.023 & & & 0.072 & & \\
\hline \multicolumn{11}{|l|}{ Trend over time } \\
\hline $\mathrm{r}$ & & -0.667 & & & -0.738 & & & -0.185 & & \\
\hline $\mathrm{p}$ & & $<0.001$ & & & $<0.001$ & & & 0.409 & & \\
\hline
\end{tabular}

juveniles, but not for EBJ (Table 2). For all lobsters, the effect of $L Z$ was marginally significant ( $p=0.042)$, with more individuals in casitas in the BRL (47.3 \pm 4.86 ind. $\left.\mathrm{ha}^{-1}\right)$ than in the ML $\left(25.1 \pm 2.96\right.$ ind. $\left.\mathrm{ha}^{-1}\right)$, but the convergence over time (negative trend for differences in means) between lagoon zones was significant (Fig. 3a, Table 2). For large juveniles, the effect of $L Z$ was not significant $(\mathrm{p}=0.079)$, with $35.4 \pm 4.12$ ind. $\mathrm{ha}^{-1}$ in casitas in the BRL and $19.5 \pm 2.37$ ind. $\mathrm{ha}^{-1}$ in casitas in the $M L$, and there was a strong convergence over time between lagoon zones (Fig. 3b, Table 2). For EBJ, in contrast, the effect of $L Z$ was significant ( $p=0.008$ ), with more individuals in casitas in the BRL $(11.9 \pm 2.37$ ind. ha $\left.{ }^{-1}\right)$ than in the ML $\left(5.5 \pm 0.93\right.$ ind. $\left.\mathrm{ha}^{-1}\right)$, and the convergence over time between lagoon zones was not significant (Fig. 3c, Table 2).

\section{Habitat characteristics of individual casita sites}

In all sites, average Braun-Blanquet scores were generally lower for VT1 and VT2 than for VT3 and VT4 (Table 3), but average scores for all VTs showed greater similarity for the $2 \mathrm{BRL}$ sites than for the $3 \mathrm{ML}$ sites (Table 3). In particular, BRL sites had the lowest scores $(<0.5$, indicating $<1 \%$ cover $)$ for the more complex VT1 and the highest scores $(>3$, indicating $>50 \%$ cover) for the less complex VT4. Average scores for all VTs varied more widely between ML sites, but the scores for VT1 were close to 1, indicating a cover of about $10 \%$, and those for VT4 were $<3$, indicating $<25 \%$ cover (Table 3 ). Mean sediment depth differed significantly among sites $\left(F_{4,307}=26.631\right.$, p $\left.<0.001\right)$, with greater values (suggestive of greater seagrass densities) for ML sites than for BRL sites (Table 3). The biomass of drift algae also differed significantly with site (Kruskal-Wallis test, $H_{4,60}=42, \mathrm{p}<0.001$ ), with far greater values for ML sites than for BRL sites (Table 3).

\section{Abundance and mean size of algal-dwelling EBJ}

The epibenthic net collected a total of 70 algaldwelling EBJ, 58 in the ML and 12 in the BRL. Their mean density was not significantly affected by Year $\left(F_{1,6}=0.424, \mathrm{p}=0.539\right)$ or $L Z \times \operatorname{Year}\left(F_{1,6}=1.192, \mathrm{p}=\right.$ $0.317)$ but differed significantly with $L Z\left(F_{1,6}=6.846\right.$, $\mathrm{p}=0.038$ ) with, on average, 3 times as many in the ML

Table 3. Habitat characteristics (mean \pm SE) of individual casita sites located in the back-reef lagoon $(\mathrm{n}=2$ sites) and mid-lagoon ( $n=3$ sites) zones. For each vegetation type (VT1 to VT4), data represent the Braun-Blanquet score averaged across 50 subareas $\left(200 \mathrm{~m}^{2}\right.$ each) into which each site was divided. For sediment depth and biomass of drift algae (Lobophora variegata), matching superscript letters denote statistically similar groups

\begin{tabular}{|c|c|c|c|c|c|c|}
\hline \multirow[t]{2}{*}{ Casita site } & \multicolumn{4}{|c|}{-Braun-Blanquet density } & \multirow{2}{*}{$\begin{array}{l}\text { Sediment } \\
\text { depth }(\mathrm{m})\end{array}$} & \multirow{2}{*}{$\begin{array}{l}\text { Biomass of drift algae } \\
\left(\text { g dry wt } \mathrm{m}^{-2}\right)\end{array}$} \\
\hline & VT1 & VT2 & VT3 & VT4 & & \\
\hline \multicolumn{7}{|c|}{ Back-reef lagoon } \\
\hline Site 1 & $0.40 \pm 0.11$ & $0.80 \pm 0.14$ & $2.30 \pm 0.16$ & $3.39 \pm 0.18$ & $0.37 \pm 0.02^{\mathrm{a}}$ & $1.27 \pm 0.51^{\mathrm{a}}$ \\
\hline Site 2 & $0.23 \pm 0.06$ & $0.54 \pm 0.16$ & $1.98 \pm 0.24$ & $3.44 \pm 0.17$ & $0.41 \pm 0.02^{\mathrm{a}}$ & $1.00 \pm 0.43^{\mathrm{a}}$ \\
\hline \multicolumn{7}{|l|}{ Mid-lagoon } \\
\hline Site 3 & $0.98 \pm 0.16$ & $0.24 \pm 0.10$ & $2.51 \pm 0.22$ & $2.90 \pm 0.16$ & $0.58 \pm 0.02^{\mathrm{b}}$ & $45.95 \pm 11.24^{\mathrm{b}}$ \\
\hline Site 4 & $0.92 \pm 0.15$ & $1.67 \pm 0.20$ & $2.90 \pm 0.24$ & $1.86 \pm 0.20$ & $0.57 \pm 0.02^{\mathrm{b}}$ & $55.72 \pm 10.26^{\mathrm{b}}$ \\
\hline Site 5 & $1.00 \pm 0.20$ & $0.50 \pm 0.14$ & $2.63 \pm 0.21$ & $2.76 \pm 0.21$ & $0.53 \pm 0.02^{\mathrm{b}}$ & $39.03 \pm 12.55^{\mathrm{b}}$ \\
\hline
\end{tabular}


$\left(9.7 \pm 3.5\right.$ ind. $\left.342 \mathrm{~m}^{-2}\right)$ than in the BRL $(3.0 \pm 1.7$ ind $342 \mathrm{~m}^{-2}$ ). The size data from these EBJ failed to comply with ANOVA assumptions as the range was much broader in the ML (6.2 to $19.0 \mathrm{~mm} \mathrm{CL}$ ) than in the BRL (6.2 to $8.5 \mathrm{~mm} \mathrm{CL),} \mathrm{and} \mathrm{were} \mathrm{thus} \mathrm{subjected} \mathrm{to} 2$ separate Mann-Whitney $U$-tests. The fist test revealed that the sizes of algal-dwelling EBJ from each lagoon zone did not differ significantly between years (ML: $U_{13,41}=$ 235, $\mathrm{p}=0.784$; BRL: $\left.U_{7,5}=12, \mathrm{p}=0.371\right)$. Therefore, we pooled data from both years to compare the sizes of EBJ between lagoon zones, which differed significantly $\left(U_{54,12}=201, \mathrm{p}=0.038\right)$. The median sizes [interquartile range] were $7.3[7.0,9.6] \mathrm{mm} \mathrm{CL}$ in the $\mathrm{ML}$ and $7.0[6.7,7.4] \mathrm{mm}$ CL in the BRL. The size distribution was skewed towards the smallest sizes (6 to $9 \mathrm{~mm}$ CL), suggesting that the net undersampled algaldwelling EBJ of $>9 \mathrm{~mm} \mathrm{CL}$. Yet $26 \%$ of those caught in the $\mathrm{ML}$, but none in the BRL, were $>9 \mathrm{~mm}$ CL. These proportions differed significantly (Fisher exact test, $\mathrm{p}=$ 0.025).

\section{Availability and microhabitat value of natural crevices}

Two of the $3 \mathrm{ML}$ sites had zero natural crevices and the other had only one small crevice. In contrast, one BRL site had 138 crevices and the other had 56, but these sites did not differ significantly $\left(\chi^{2}=4.591, \mathrm{df}=2\right.$, $\mathrm{p}=0.101)$ in their proportions of small $(67 \%$ on average), medium $(21 \%)$, and large $(12 \%)$ crevices. In total, we observed 200 lobsters residing in crevices, 191 at BRL sites ( $63 \%$ of which were EBJ) and 9 at the ML site with a single crevice (89\% of which were EBJ). Their size range was broader in the BRL (7.0 to $55.0 \mathrm{~mm} \mathrm{CL}$ ) than in the ML (7.5 to $21.0 \mathrm{~mm} \mathrm{CL}$ ) (Fig. 4a), but the mean sizes (BRL: $18.3 \pm 0.53 \mathrm{~mm} \mathrm{CL,}$ ML: $17.1 \pm 1.39 \mathrm{~mm}$ CL) did not differ significantly (1-way ANOVA, $\left.F_{1,198}=0.151, \mathrm{p}=0.698\right)$. Interestingly, however, the mean size of lobsters using crevices at BRL sites was significantly smaller (1-way ANOVA, $F_{1,534}=40.77, \mathrm{p}<0.001$ ) during our study period (i.e. after casita deployment) than prior to casita deployment $(23.1 \pm 0.49 \mathrm{~mm} \mathrm{CL}, \mathrm{n}=343$, data from BrionesFourzán \& Lozano-Álvarez 2001b).

When occupied, the single small crevice at the ML site harbored 1 lobster, except on one occasion when it harbored 2 lobsters. In the BRL, occupied crevices harbored 1 to 6 lobsters (1.6 on average), but the frequencies of occupied crevices harboring $1,2,3$, and 4 to 6 lobsters $(78,20,11$, and 8 , respectively) differed significantly $\left(\chi^{2}=12.525, \mathrm{df}=2, \mathrm{p}=0.002\right)$ from expected zero-truncated frequencies $(65,35,13$, and 4 , respectively). In particular, there were more crevices harboring 1 and 4 to 6 lobsters, and less harboring 2 lobsters, than expected by chance. These results reflect the tendency of lobsters to aggregate but show that few crevices were sufficiently large so as to offer the potential for gregariousness.

\section{Microhabitat value of casitas}

In total, we observed 3707 lobsters using casitas, 2079 at BRL sites (size range: 7.0 to $79.0 \mathrm{~mm} \mathrm{CL}$, Fig. $4 \mathrm{~b}$ ) and 1628 at ML sites (size range: 6.2 to 87.0 mm CL, Fig. 4b). Their mean size (BRL: $30.3 \pm 0.28 \mathrm{~mm}$ CL, ML: $31.9 \pm 0.35 \mathrm{~mm}$ CL) was significantly affected by $T\left(F_{10,20}=6.386, \mathrm{p}<0.001\right)$, but not by $L Z\left(F_{1,3}=\right.$ $0.564, \mathrm{p}=0.507)$ or $L Z \times T\left(F_{10,20}=2.123, \mathrm{p}=0.073\right)$. These results support our previous finding that lobsters did not tend to move from ML sites to BRL sites as they grew (Briones-Fourzán et al. 2007). At BRL sites, lobsters using casitas were significantly larger than lobsters using crevices (1-way ANOVA with log-trans-

\section{a Crevices}

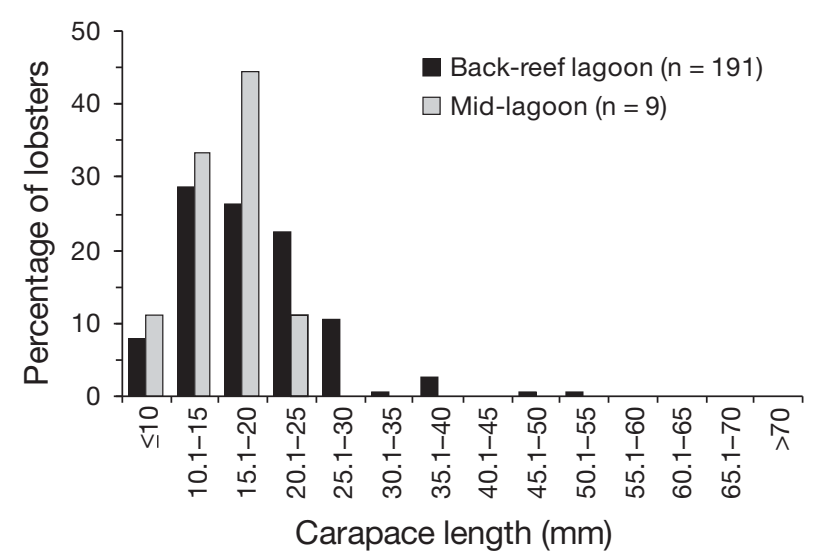

\section{b Casitas}

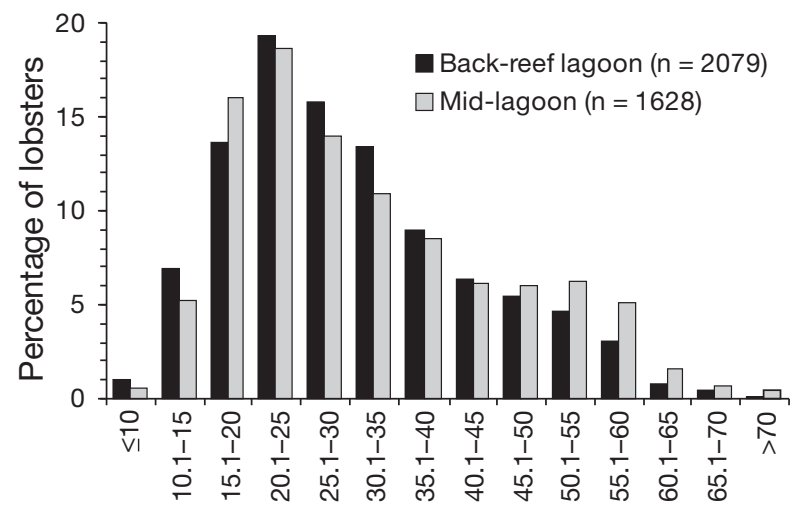

Carapace length $(\mathrm{mm})$

Fig. 4. Panulirus argus. Size distribution of lobsters residing (a) in crevices and (b) in casitas at sites in the back-reef lagoon ( $\mathrm{n}=2$ sites) and the mid-lagoon ( $\mathrm{n}=3$ sites) zones across the study period (September 1998 to November 2002) 
formed data, $F_{1,2276}=228.26$, $\mathrm{p}<0.001$ ) but were substantially smaller than lobsters dwelling in the nearby reef habitat $(58.2 \pm 1.11 \mathrm{~mm} \mathrm{CL}, \mathrm{n}=185$, LozanoÁlvarez et al. 2007), indicating that casitas at BRL sites did not tend to attract larger reef-dwelling lobsters.

In both lagoon zones, the distribution of lobsters among casitas differed significantly from random (ML: $\chi^{2}=1169.6, \mathrm{df}=10, \mathrm{p}<0.001$; BRL: $\chi^{2}=1435.5, \mathrm{df}=10$, $\mathrm{p}<0.001$ ) but there were proportionally more empty casitas and casitas harboring a single lobster in the ML $(28.3 \%$ and $23.5 \%$, respectively) than in the BRL (13.6\% and $15.9 \%$, respectively), and more casitas harboring groups of 8 or more lobsters in the BRL $(20.4 \%)$ than in the ML (7\%) (Fig. 5). Occupied casitas harbored 1 to 53 lobsters (5.5 on average) in the BRL, and 1 to 25 lobsters (3.5 on average) in the ML.

Of the 28 large juveniles marked in each lagoon zone, 22 were resighted at ML sites and 26 at BRL sites, yielding a similar site fidelity between $L Z$ (Fisher exact test $\mathrm{p}=0.252$ ). Individuals that shifted casitas overnight were usually found in an adjacent casita, but $43.5 \%$ individuals at ML sites were consistently found in their original casita and no individual used more than 3 different casitas, whereas only $11.5 \%$ individuals at BRL sites were found in their original casita and some individuals used up to 5 different casitas. Therefore, large juveniles showed a greater casita fidelity at ML sites $\left(\chi^{2}=6.661\right.$; df $=2, p=0.036)$, which was reflected in their shorter range of shelter use $(5.3 \pm 1.38 \mathrm{~m})$ relative to large juveniles at BRL sites $(11.1 \pm 1.60 \mathrm{~m})\left(t_{47}=2.689, \mathrm{p}=0.01\right)$.

\section{Effect of habitat complexity on the shift of EBJ to casitas}

The relationship between the average numbers of EBJ residing in casitas (dependent variable) and the

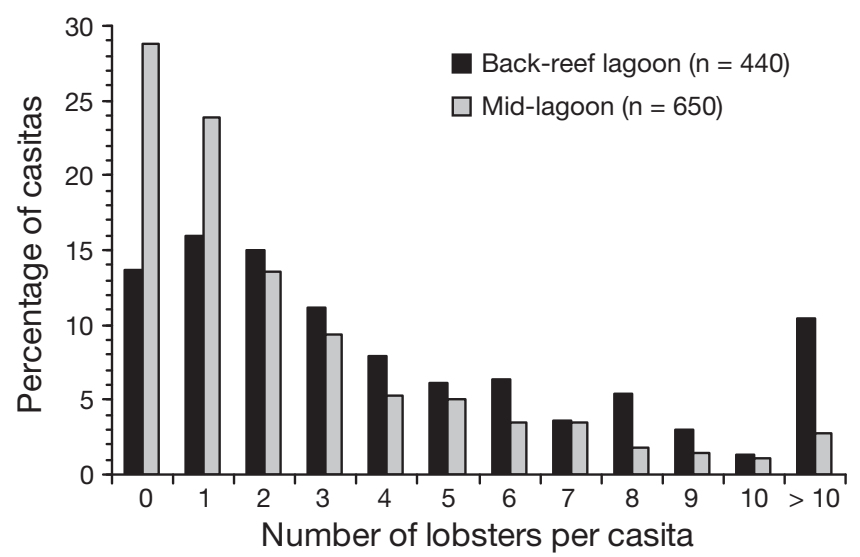

Fig. 5. Panulirus argus. Distribution of lobsters among casitas at sites in the back-reef lagoon ( $\mathrm{n}=2$ sites) and the midlagoon ( $\mathrm{n}=3$ sites) zones across the study period (September 1998 to November 2002) average numbers of large juveniles residing in casitas (covariate) by $L Z$ (categorical predictor) is depicted in Fig. 6a (raw data) and 6b (log-transformed data, $\mathrm{n}=22$ surveys). ANCOVA results (Table 4) showed that, after controlling for the significant covariate effect $(p=0.006)$, significantly more EBJ shifted to casitas in the BRL than in the ML ( $p=$ 0.007), with both predictors explaining a similar percentage $(25 \%)$ of the variability in the numbers of EBJ shifting to casitas (Table 4).

In total, we observed 449 EBJ residing in casitas in the BRL and 354 in the ML. Their size distribution (Fig. 7) shows that EBJ tended to shift to casitas sooner in the BRL than in the ML. Sufficient data for RM-ANOVA were obtained in 19 of the 22 surveys. The analysis revealed that EBJ residing in casitas were slightly but significantly smaller in the BRL $(15.5 \pm 0.29 \mathrm{~mm}$ CL) than in the $\mathrm{ML}(16.4 \pm 0.28 \mathrm{~mm} \mathrm{CL})\left(F_{1,3}=14.769, \mathrm{p}=0.031\right)$, with no significant effects of $T\left(F_{17,51}=1.396, \mathrm{p}=0.172\right)$ or $L Z \times T\left(F_{17,51}=1.497, \mathrm{p}=0.128\right)$.
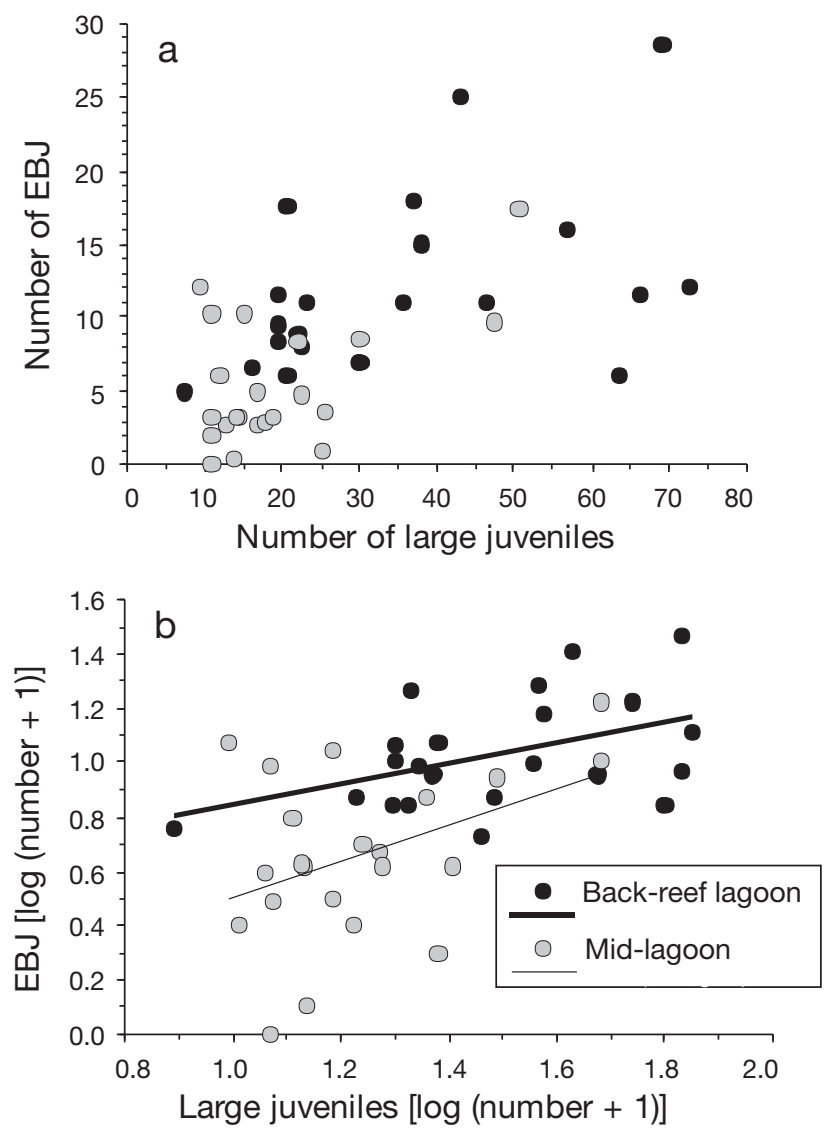

Fig. 6. Panulirus argus. Relationship between the average numbers of early benthic juveniles (EBJ; $\leq 20 \mathrm{~mm}$ carapace length [CL]) and large juveniles (>20 $\mathrm{mm} \mathrm{CL}$ ) residing in casitas at sites in the back-reef lagoon ( $\mathrm{n}=2$ sites) and the mid-lagoon ( $\mathrm{n}=3$ sites) (a) derived from raw data, (b) derived from data transformed to $\log ($ number +1$)$. Each dot represents 1 survey $(n=22)$ 
Table 4. Panulirus argus. ANCOVA to test for effects of lagoon zone (categorical predictor with 2 levels: back-reef lagoon and mid-lagoon) and the numbers of large juveniles (>20 mm carapace length; CL) residing in casitas (covariate) on the numbers of early benthic juveniles $(\leq 20 \mathrm{~mm} \mathrm{CL})$ shifting from the vegetated habitat to casitas

\begin{tabular}{|lcccccc|}
\hline Effect & $\mathrm{SS}$ & $\mathrm{df}$ & $\mathrm{MS}$ & $F$ & $\mathrm{p}$ & $\mathrm{R}^{2}$ \\
\hline Model & 1.990 & 2 & 0.995 & 16.597 & $<0.001$ & 0.447 \\
Intercept & 0.032 & 1 & 0.032 & 0.539 & 0.467 & \\
Lagoon zone & 0.480 & 1 & 0.480 & 8.001 & 0.007 & 0.251 \\
Large juveniles & 0.496 & 1 & 0.496 & 8.273 & 0.006 & 0.256 \\
Error & 2.458 & 41 & 0.060 & & & \\
\hline
\end{tabular}

In seagrass communities, structural complexity depends on a combination of plant attributes such as density, height, functional form, and biomass (Heck \& Thoman 1981, Stoner \& Lewis 1985, Hemminga \& Duarte 2000, Heck et al. 2003). We assessed vegetation complexity at casita sites using a combination of sediment depth (a predictor of seagrass density), biomass of drift algae, and percent cover of 4 VTs reflecting a decreasing gradient of macrophyte densities (excluding drift algae) and seagrass heights, in particular of the dominant seagrass Thalassia testudinum. Our results agree with previous findings in that, despite a patchy distribution and seasonal variations in some attributes, vegetation complexity is typically greater in the ML than in the BRL (van Tussenbroek 1994, 1995, 1998, ReyesZavala 1998, Ruiz-Rentería et al. 1998, Enríquez et al. 2001, van Tussenbroek \& van Dijk 2007). Total seagrass biomass over the Puerto Morelos reef lagoon falls in the lower range of values found elsewhere in the Caribbean (van Tussenbroek 1998), partially explaining the lower abundances of VT1 and VT2 relative to VT3 and VT4 at all sites. Lipcius et al. (1998) found that survival of large juveniles of Panulirus argus (31 to $76 \mathrm{~mm} \mathrm{CL}$ ) tethered to the substrate was better predicted by algal biomass than by seagrass biomass, but macroalgal densities did not vary as widely as seagrass densities in our VTs. However, relative to ML sites, BRL sites had a thinner sediment layer and hence less area covered by VT1 and more by VT4, and a much lower biomass of drift algae.

These findings are relevant because (1) it is the drift algae that more substantially increase the refuge value of vegetated habitats for algal-dwelling EBJ given their highly intricate (e.g. Laurencia spp.) or convoluted forms (e.g. Lobophora variegata) (Marx \& Herrnkind 1985, Herrnkind \& Butler 1986, Butler et al. 1997, Briones-Fourzán \& Lozano-Álvarez 2001a, Cruz et al. 2007), and (2) density and height of Thalassia testudinum are important predictors of within-canopy light attenuation (Enríquez and Pantoja-Reyes 2005), which may confer an additional advantage to EBJ over their main predators (diurnal fishes). Thus, algaldwelling EBJ are likely to fare better at ML sites than at BRL sites, a contention partially supported by their higher densities and broader size range in the $\mathrm{ML}$, although their relative survival rates in the lagoon zones are yet to be compared (e.g. with tethering techniques). Conversely, the ensuing lobster phases that depend on crevice shelter for survival would likely fare better in the BRL, where crevices abound, than in the $\mathrm{ML}$, where crevices are nearly non-existent. Indeed, vegetation. 
across 13 surveys prior to casita deployment, mean densities of crevice-dwelling lobsters were much lower at $\mathrm{ML}$ sites $\left(0.1 \pm 0.08\right.$ ind. $\left.\mathrm{ha}^{-1}\right)$ than at BRL sites $\left(14.2 \pm 1.53\right.$ ind. ha $^{-1}$ ) (data from Briones-Fourzán \& Lozano-Álvarez 2001b). Although lobsters using natural crevices at BRL sites were typically small given the small dimensions of most crevices, their mean size further decreased after casita deployment. This finding, in conjunction with the similar short-term site fidelity (this study) and long-term site fidelity (i.e. persistence, Briones-Fourzán et al. 2007) of large juveniles at casita sites in both lagoon zones, indicates that casitas provided better refuge for large juvenile lobsters than available crevices.

As the narrow entrance height of casitas excludes large predators, lobsters sheltered in casitas are at low risk of predation (Eggleston et al. 1990, BrionesFourzán et al. 2007). Predation risk would be expected to increase as juvenile lobsters leave their shelters and disperse to forage, especially over areas with less complex vegetation (Herrnkind \& Butler 1986), yet large juveniles tended to shift more between casitas at BRL sites than at ML sites. However, individuals that shifted casitas were usually found in an adjacent casita, a relatively short distance ( $\geq 20 \mathrm{~m}$ ) that probably entailed a low risk (Acosta 1999, Lozano-Álvarez et al. 2003). On the other hand, although food resources (small invertebrates) for juvenile Panulirus argus abound in the reef lagoon (Briones-Fourzán et al. 2003), the immediate availability of small prey tends to be greater in complex vegetation (Sosa-Cordero et al. 1998, Hemminga \& Duarte 2000, Briones-Fourzán et al. 2003). Thus, it could be speculated that large juveniles at ML sites did not need to venture far from their casitas to forage, whereas those at BRL sites could risk foraging over longer distances because casitas at these sites harbored larger conspecific aggregations, potentially exerting a stronger guide effect and offering a greater potential for group defense.

This combination of guide effect and group defense benefits likely underlies the higher microhabitat value of casitas relative to that of natural crevices available in the reef lagoon. The guide effect is particularly beneficial to lobsters of $<50 \mathrm{~mm}$ CL (Childress \& Herrnkind 2001b). The group defense directly benefits the larger lobsters but also indirectly benefits the smaller lobsters residing with large conspecifics (Eggleston \& Lipcius 1992, Briones-Fourzán et al. 2008), and casitas harbored lobsters over a broader size range than available crevices. At BRL sites there were, on average, 5.5 lobsters per occupied casita versus 1.6 lobsters per occupied crevice, which, combined with the lower complexity of the local vegetated habitat, would explain the tendency of EBJ to shift to casitas sooner. At ML sites, in contrast, occupied casitas harbored
3.5 lobsters on average, which, together with the higher complexity of the local vegetation, would explain the more delayed shift of EBJ to casitas.

The present study contributes towards understanding potential effects of the landscape context on the performance of artificial shelters for benthic species that undergo habitat shifts. For the particular case of casitas and juvenile Panulirus argus lobsters, we propose the following conceptual model: given a meaningful supply of algal-dwelling EBJ, density enhancement of juvenile $P$. argus with casitas would be more immediate where the local vegetation ceases to confer antipredator refuge sooner, but would tend to increase over time in more complex vegetated habitats as gradually more lobsters shift to, and persist in, casitas.

Acknowledgements. We thank F. Negrete-Soto and C. Barradas-Ortiz for their permanent technical support and L. Álvarez-Filip, V. Monroy-Velázquez, I. Segura-García, E. Rojas-Francisco, L. González-González, and C. Rivera-Díaz for their help in field work. B. van Tussenbroek advised on the assessment of vegetation. This study was partially funded by the Consejo Nacional de Ciencia y Tecnología, Mexico (Project 1141-N). Annual research permits were issued by the Comisión Nacional de Acuacultura y Pesca, Mexico.

\section{LITERATURE CITED}

Acosta CA (1999) Benthic dispersal of Caribbean spiny lobsters among insular habitats: implications for the conservation of exploited marine species. Conserv Biol 13: $603-612$

Briones-Fourzán P, Lozano-Álvarez E (2001a) The importance of Lobophora variegata (Phaeophyta: Dictyotales) as a habitat for small juveniles of Panulirus argus (Decapoda: Palinuridae) in a tropical reef lagoon. Bull Mar Sci 68: 207-219

Briones-Fourzán P, Lozano-Álvarez E (2001b) Effects of artificial shelters (Casitas) on the abundance and biomass of juvenile spiny lobsters Panulirus argus in a habitatlimited tropical reef lagoon. Mar Ecol Prog Ser 221: 221-232

> Briones-Fourzán P, Lozano-Álvarez E (2008) Coexistence of congeneric spiny lobsters on coral reefs: differences in conspecific aggregation patterns and their potential antipredator benefits. Coral Reefs 27:275-287

Briones-Fourzán P, Castañeda-Fernández de Lara V, LozanoÁlvarez E, Estrada-Olivo J (2003) Feeding ecology of the three juvenile phases of the spiny lobster Panulirus argus in a tropical reef lagoon. Mar Biol 142:855-865

Briones-Fourzán P, Pérez-Ortiz M, Lozano-Álvarez E (2006) Defense mechanisms and anti-predator behavior in two sympatric species of spiny lobsters, Panulirus argus and P. guttatus. Mar Biol 149:227-239

Briones-Fourzán P, Lozano-Álvarez E, Negrete-Soto F, Barradas-Ortiz C (2007) Enhancement of juvenile Caribbean spiny lobsters: an evaluation of changes in multiple response variables with the addition of large artificial shelters. Oecologia 151:401-416

Briones-Fourzán P, Candela J, Lozano-Álvarez E (2008) Postlarval settlement of the spiny lobster Panulirus argus along the Caribbean coast of Mexico: patterns, influence 
of physical factors and possible sources of origin. Limnol Oceanogr 53:970-985

Butler MJ IV, Herrnkind WF (1997) A test of recruitment limitation and the potential for artificial enhancement of spiny lobster (Panulirus argus) populations in Florida. Can J Fish Aquat Sci 54:452-463

Butler MJ, Herrnkind WF, Hunt JH (1997) Factors affecting the recruitment of juvenile Caribbean spiny lobsters dwelling in macroalgae. Bull Mar Sci 61:3-19

Childress MJ, Herrnkind WF (1994) The behavior of juvenile Caribbean spiny lobster in Florida Bay: seasonality, ontogeny and sociality. Bull Mar Sci 54:819-827

Childress MJ, Herrnkind WF (2001a) Influence of conspecifics on the ontogenetic habitat shift of juvenile Caribbean spiny lobsters. Mar Freshw Res 52:1077-1084

> Childress MJ, Herrnkind WF (2001b) The guide effect influence on the gregariousness of juvenile Caribbean spiny lobsters. Anim Behav 62:465-472

Cohen AC Jr (1960) Estimating the parameter in a conditional Poisson distribution. Biometrics 16:203-211

> Cox C, Hunt JH, Lyons WG, Davis GE (1997) Nocturnal foraging of the Caribbean spiny lobster (Panulirus argus) on offshore reefs of Florida, USA. Mar Freshw Res 48: 671-679

Cruz R, Suárez AM, Lalana R, Adriano R (2007) Predicción del reclutamiento y la población en la fase puerulo, algal y juvenil de la langosta (Panulirus argus) en asociaciones de algas. Rev Invest Mar 28:11-19

Dahlgren CP, Eggleston DB (2000) Ecological processes underlying ontogenetic habitat shifts in a coral reef fish. Ecology 81:2227-2240

Eggleston DB, Lipcius RN (1992) Shelter selection by spiny lobsters under variable predation risk, social conditions, and shelter size. Ecology 73:992-1011

Eggleston DB, Lipcius RN, Miller DL, Cobá-Cetina L (1990) Shelter scaling regulates survival of Caribbean spiny lobster Panulirus argus. Mar Ecol Prog Ser 62:79-88

Eggleston DB, Ehterington LL, Elis WE (1998) Organism response to habitat patchiness: species and habitatdependent recruitment of decapod crustaceans. J Exp Mar Biol Ecol 223:111-132

Enríquez S, Pantoja-Reyes N (2005) Form-function analysis of the effect of canopy morphology on leaf self-shading in the seagrass Thalassia testudinum. Oecologia 145: 235-243

Enríquez S, Marbà N, Duarte CM, van Tussenbroek BI, Reyes-Zavala G (2001) Effects of seagrass Thalassia testudinum on sediment redox. Mar Ecol Prog Ser 219: 149-158

Fourqurean JW, Willsie A, Rose CD, Rutten LM (2001) Spatial and temporal pattern in seagrass community composition and productivity in south Florida. Mar Biol 138:341-354

Fourqurean JW, Boyer JN, Durako MJ, Hefty LN, Peterson BJ (2003) Forecasting responses of seagrass distributions to changing water quality using monitoring data. Ecol Appl 13:474-489

Heck KL Jr, Thoman TA (1981) Experiments on predatorprey interactions in vegetated aquatic habitats. J Exp Mar Biol Ecol 53:125-134

Heck KL Jr, Hays G, Orth RJ (2003) Critical evaluation of the nursery role hypothesis for seagrass meadows. Mar Ecol Prog Ser 253:123-136

Hemminga MA, Duarte CM (2000) Seagrass ecology. Cambridge University Press, Cambridge

> Herrnkind WF, Butler MJ (1986) Factors regulating postlarval settlement and juvenile microhabitat use by spiny lobsters Panulirus argus. Mar Ecol Prog Ser 34:23-30

Hovel KA, Lipcius RN (2001) Habitat fragmentation in a sea- grass landscape: patch size and complexity control blue crab survival. Ecology 82:1814-1829

Howell DC (2002) Statistical methods for psychology, 5th edn. Duxbury, Pacific Grove, CA

- Lipcius RN, Eggleston DB, Miller DL, Luhrs TC (1998) The habitat-survival function for Caribbean spiny lobster: an inverted size effect and non-linearity in mixed algal and seagrass habitats. Mar Freshw Res 49:807-816

Lozano-Álvarez E, Briones-Fourzán P, Phillips BF (1991) Fishery characteristics, growth, and movements of the spiny lobster Panulirus argus in Bahia de la Ascension, Mexico. Fish Bull (Wash DC) 89:79-89

Lozano-Álvarez E, Briones-Fourzán P, Ramos-Aguilar ME (2003) Distribution, shelter fidelity, and movements of subadult spiny lobsters (Panulirus argus) in areas with artificial shelters. J Shellfish Res 22:533-540

Lozano-Álvarez E, Briones-Fourzán P, Osorio-Arciniegas A, Negrete-Soto F, Barradas-Ortiz C (2007) Coexistence of congeneric spiny lobsters on coral reefs: differential use of shelter resources and vulnerability to predators. Coral Reefs 26:361-373

Marx J, Herrnkind WF (1985) Macroalgae (Rhodophyta: Laurencia spp.) as habitat for young juvenile spiny lobsters, Panulirus argus. Bull Mar Sci 36:423-431

> Mintz JD, Lipcius RN, Eggleston DB, Seebo MS (1994) Survival of juvenile Caribbean spiny lobster: effects of shelter size, geographic location, and conspecific abundance. Mar Ecol Prog Ser 112:255-266

> Nizinski MS (2007) Predation in subtropical soft-bottom systems: spiny lobster and molluscs in Florida Bay. Mar Ecol Prog Ser 345:185-197

> Orth RJ, Heck KL, van Montfrans J (1984) Faunal communities in seagrass beds: a review of the influence of plant structure and prey characteristics on predator-prey relationships. Estuaries 7:339-350

> Powers SP, Grabowski JH, Peterson CH, Lindberg WJ (2003) Estimating enhancement of fish production by offshore artificial reefs: uncertainty exhibited by divergent scenarios. Mar Ecol Prog Ser 264:265-277

> Ratchford SG, Eggleston DB (1998) Size- and scale-dependent chemical attraction contribute to an ontogenetic shift in sociality. Anim Behav 56:1027-1034

Reyes-Zavala G (1998) Monitoreo de las macrofitas bénticas de la laguna arrecifal de Puerto Morelos, Q. R. BSc thesis, Universidad Nacional Autónoma de México, Mexico City

Ruiz-Rentería F, van Tussenbroek BI, Jordán-Dahlgren E (1998) Puerto Morelos, Quintana Roo, México. In: Kjerve B (ed) CARICOMP-Caribbean coral reef, seagrass, and mangrove sites. UNESCO, Paris, p 56-66

Smith KN, Herrnkind WF (1992) Predation on early juvenile spiny lobsters Panulirus argus (Latreille): influence of size and shelter. J Exp Mar Biol Ecol 157:3-18

Sosa-Cordero E, Arce A, Aguilar-Dávila W, RamírezGonzález A (1998) Artificial shelters for spiny lobster Panulirus argus (Latreille): an evaluation of occupancy in different benthic habitats. J Exp Mar Biol Ecol 229:1-18

> Stoner AW (2003) What constitutes essential nursery habitat for a marine species? A case study of habitat form and function for queen conch. Mar Ecol Prog Ser 257:275-289

Stoner AW, Lewis FG (1985) The influence of quantitative and qualitative aspects of habitat complexity in tropical seagrass meadows. J Exp Mar Biol Ecol 94:19-44

> Tanner JE (2006) Landscape ecology of interactions between seagrass and mobile epifauna: the matrix matters. Estuar Coast Shelf Sci 68:404-412

van Tussenbroek BI (1994) Spatial and seasonal variability in biomass and leaf morphology of the manatee seagrass, 
Syringodium filiforme, in a tropical coral reef lagoon, Mexico. An Inst Cienc del Mar y Limnol Univ Nal Autón México 21:15-22

van Tussenbroek BI (1995) Thalassia testudinum leaf dynamics in a Mexican Caribbean coral reef lagoon. Mar Biol 122:33-40

> van Tussenbroek BI (1998) Above- and below-ground biomass and production by Thalassia testudinum in a tropical reef lagoon. Aquat Bot 61:69-82

Editorial responsibility: Kenneth Heck Jr., Dauphin Island, Alabama, USA van Tussenbroek BI, van Dijk KJ (2007) Spatial and temporal variability in biomass and production of psammophytic Halimeda incrassata (Bryopsidales, Chlorophyta), in a Caribbean reef lagoon. J Phycol 43:69-77

Werner EE, Gilliam JF (1984) The ontogenetic niche and species interactions in size-structured populations. Annu Rev Ecol Syst 15:393-425

Zar JH (1999) Biostatistical analysis, 4th edn. Prentice-Hall, Englewood Cliffs, NJ

Submitted: December 15, 2008; Accepted: September 6, 2009 Proofs received from author(s): November 18, 2009 